0305-750X(94)E0029-W

\title{
The Origins and Practice of Participatory Rural Appraisal*
}

\author{
ROBERT CHAMBERS $\dagger$ \\ Institute of Development Studies, Brighton
}

\begin{abstract}
Summary. - Participatory Rural Appraisal (PRA) describes a growing family of approaches and methods to enable local people to share, enhance and analyze their knowledge of life and conditions, to plan and to act. PRA has sources in activist participatory research, agroecosystem analysis, applied anthropology, field research on farming systems, and rapid rural appraisal (RRA). In RRA information is more elicited and extracted by outsiders; in PRA it is more shared and owned by local people. Participatory methods include mapping and modeling, transect walks, matrix scoring, seasonal calendars, trend and change analysis, well-being and wealth ranking and grouping, and analytical diagramming. PRA applications include natural resources management, agriculture, poverty and social programs, and health and food security. Dominant behavior by outsiders may explain why it has taken until the 1990s for the analytical capabilities of local people to be better recognized and for PRA to emerge, grow and spread.
\end{abstract}

\section{INTRODUCTION}

The past decade has witnessed more shifts in the rhetoric of rural development than in its practice. These shifts include the now familiar reversals from top-down to bottom-up, from centralized standardization to local diversity, and from blueprint to learning process. Linked with these, changes have begun in modes of learning. The move here is away from extractive survey questionnaires and toward new approaches and methods for participatory appraisal and analysis in which more of the activities previously appropriated by outsiders are instead carried out by local rural or urban people themselves. The question now is how much potential these approaches and methods have for making participation more practical and the rhetoric more real.

In these changes, a part has been played by two closely related families of approaches and of methods, often referred to as rapid rural appraisal (RRA) which developed and spread especially in the 1980s, and its further evolution into participatory rural appraisal (PRA) which has developed and spread fast in the 1990s. The purpose of this paper is to outline the origins, principles, approaches, methods and applications of PRA from a perspective in early 1994.

\section{PARENTS AND RELATIVES OF PRA}

The approaches and methods described as PRA are evolving so fast that to propose one secure and final definition would be unhelpful. As PRA further develops, there will be changes in what the label can usefully refer to, and perhaps in the label itself. PRA has been called "an approach and methods for learning about rural life and conditions from, with and by rural people." The prepositions have sometimes been reversed in order to read 'by, with and from.' The phenomenon described is, though, more than just learning. It is a process which extends into analysis, planning and action. PRA as a term is also used to describe a variety of approaches. To cover these, a recent description of PRA is "a family of approaches and methods to enable rural people to share, enhance, and analyze their knowledge of life and conditions, to plan and to act."

PRA as it exists in the early to mid-1990s has several sources. It has evolved from, draws on, and resonates with, several traditions. Some of its methods do appear to be new; but some have been rediscoveries

*This paper is the first in a three-part series examining participating rural appraisal.

tThis paper is based on the work and innovations of many people, too numerous to name, but I thank them all. For comments on earlier versions I am grateful to Tony Dunn, James Mascarenhas, Jules Pretty and two anonymous referees. Responsibility for errors, omission and opinions is mine alone. Final revision accepted: February 21, 1994. 
(for antecedents see, for example, Whyte, 1977; Pelto and Pelto, 1978; and Rhoades, 1992). In understanding what has happened, it makes no sense to try to separate out causes, effects, innovations, influences and diffusion as though they follow straight lines. In a world of continuously quicker and closer communication, the transfer and sharing of ideas have become more rapid and untraceable. So these sources and traditions have, like flows in a braided stream, intermingled more and more over the past decade, and each also continues in several forms; but directly or indirectly all have contributed to a confluence in PRA; and as with other confluences, the flow has speeded up, and innovation and change have accelerated.

Five streams which stand out as sources and parallels to PRA are, in alphabetical order:

- activist participatory research;

- agroecosystem analysis;

- applied anthropology;

- field research on farming systems;

- rapid rural appraisal.

\section{(a) Activist participatory research}

The term "activist participatory research" is used to refer to a family of approaches and methods which use dialogue and participatory research to enhance people's awareness and confidence, and to empower their action. Activist participatory research in this sense owes much to the work and inspiration of Paulo Freire, to his book Pedagogy of the Oppressed (1968), and to the practice and experience of consciencization in Latin America. The Freirian theme, that poor and exploited people can and should be enabled to conduct their own analysis of their own reality has been widely influential, even though it has remained a minority view among development professionals as a whole. Two related schools have been known as participatory research, and participatory action research (PAR).

Participatory research has been associated with the adult education movement since at least 1975 (Convergence 1975; 1981; 1988, No. 3). Regional networks were set up. An African regional Workshop on Participatory Research was held in Tanzania in 1979 (Kassam and Mustafa, 1982). In India, the Society for Participatory Research in $\Lambda$ sia (SPR in Asia 1982) has sought to spread the philosophy and practice of participatory research. Participatory research has been conducted in widely differing conditions (Rahman, 1984). For example, in Bangladesh, as recorded in The Net (BRAC, 1983), poor and powerless people took part in investigation and analysis of the power structure in 10 villages, and of how benefits directed toward them by the government were intercepted by the local elite. In the United States, the Highlander Center in rural Appalachia has worked to enable underprivileged communities to gain confidence in their own knowledge and abilities, and to take political action (Gaventa and Lewis, 1991).

For its part, participatory action research (PAR) has been parallel and overlapping with participatory research, and has had strong associations with industry and agriculture (Whyte, 1991). The techniques used in PAR (summarized in Cornwall, Guijt and Welbourn, 1993, p. 25) include collective research through meetings and sociodramas, critical recovery of history, valuing and applying "folk culture," and the production and diffusion of new knowledges through written, oral and visual forms.

Activist participatory research has taken different forms and has been practised by people with a range of ideological positions, from radical crypto-paternalism to open-ended facilitation. Its special focus on the underprivileged and on political action has threatened established interests, whether political or professional, and limited its spread. In practice, much PRA has similarly been concerned with poverty and equity. The contributions of the activist participatory research stream to PRA have been more through concepts than methods. They have in common three prescriptive ideas:

- that poor people are creative and capable, and can and should do much of their own investigation, analysis and planning;

- that outsiders have roles as convenors, catalysts and facilitators;

- that the weak and marginalized can and should be empowered.

\section{(b) Agroecosystem analysis}

Agroecosystem analysis (Conway 1985, 1986, 1987) was developed in Thailand from 1978 onward, initially at the University of Chiang Mai, by Gordon Conway and his colleagues (Gypmantasiri et al. 1980). It spread first through Southeast Asia and then elsewhere. Drawing on systems and ecological thinking, it combines analysis of systems and system properties (productivity, stability, sustainability, and equitability) with pattern analysis of space (maps and transects), time (seasonal calendars and long-term trends), flows and relationships (flow, causal, Venn and other diagrams), relative values (bar diagrams of relative sources of income etc.), and decisions (decision trees and other decision diagrams). The approach was further developed by Conway and others with the Aga Khan Rural Support Programme (Pakistan) for application in villages in Northern Pakistan, where it took a form which led to identification and assessment of practical hypotheses for action.

Agroecosystem analysis was so powerful and practical that it quickly overlapped with and contributed to much RRA. In some cases, either or both 
labels could be used to describe what was done. Some of the major contributions of agroecosystem analysis to current RRA and PRA have been:

- transects (systematic walks and observation);

- informal mapping (sketch maps drawn on site); - diagramming (seasonal calendars, flow and causal diagrams, bar charts, Venn or chapati diagrams);

- innovation assessment (scoring and ranking different actions).

\section{(c) Applied anthropology}

Social anthropology in its classical forms has been concerned more with understanding than with changing, but especially in the 1980s, applied anthropology, and development anthropology, became more recognized as legitimate and useful activities. In the United States, the Institute for Development Anthropology established a network and a regular Bulletin. A very few social anthropologists found their way into the International Agricultural Research Centers, where they had an influence disproportionate to their tiny numbers, and the social anthropologists in aid agencies rose in numbers and status, though they were still few. Social anthropologists helped development professionals generally to appreciate better the richness and validity of rural people's knowledge (e.g., IDS, 1979; Brokensha, Warren and Werner, 1980), and to distinguish the etic - the outsider's mental frame, categories and world view, and the emic - those of the insider. In addition, The Art of the Informal Agricultural Survey (1982), by Robert Rhoades, a social anthropologist at the International Potato Center in Peru, was widely read and influential far beyond the informal form of its publication.

In one methodological stream, the approaches of social anthropology were adopted in health and nutrition in rapid assessment procedures (RAP) (Scrimshaw and Hurtado, 1987; Scrimshaw and Gleason, 1992) and in rapid ethnographic assessment (REA) (Bentley et al. 1988), which variously used conversations, observation, informal interviews, focus groups, and careful and detailed recording.

PRA represents an extension and application of social anthropological insights, approaches and methods, crossfertilized with others. Some of the many insights and contributions coming from and shared with social anthropology have been:

- the idea of field learning as flexible art rather

than rigid science;

- the value of field residence, unhurried participant-observation, and conversations;

- the importance of attitudes, behavior and rapport;

- the emic-etic distinction;

- the validity of indigenous technical knowledge.

\section{(d) Field research on farming systems}

Field research on farming systems, whether by social anthropologists, geographers, agricultural economists or biological scientists, has revealed the complexity, diversity and rationality of much apparently untidy and unsystematic farming practice. Among those who showed its good sense were, in the 1960s, D. G. R. Belshaw at Makerere University in Uganda, and in the 1970s, David Norman and his colleagues at Ahmadu Bello University in Northern Nigeria (see e.g., Norman, 1975 for the value of mixed cropping), Michael Collinson in Tanzania, Richard Harwood in Thailand (Harwood, 1979) and Peter Hildrebrand in Guatemala. Farming systems research (FSR) (Gilbert, Norman and Winch 1980, Shaner, Philipp and Schmehl, 1982, FSSP, 1987) systematized methods for investigating, understanding, and prescribing for farming system complexity, but sometimes bogged down in ponderous surveys and data overload.

A parallel stream of research drew attention to farmers" capabilities. Stephen Biggs in describing "informal R and D" (1980), Paul Richards in his classic Indigenous Agricultural Revolution (1985), and Roland Bunch in Two Ears of Corn (1985) were among those who showed and recognized that farmers were experimenters. Farmers' participation in agricultural research became a focus (e.g., Farrington, 1988; Farrington and Martin, 1988; Chambers, Pacey and Thrupp, 1989; Ashby, 1990). Clive Lightfoot and his colleagues pioneered analytical and flow diagramming by farmers (e.g., Lightfoot, Noble and Morales 1991; Lightfoot and Minnick, 1991; Lightfoot and Noble, 1993) and Jacqueline Ashby at CIAT in Colombia and Michel Pimbert at ICRISAT in India showed through widely influential videos how capable farmers, women and men, could be in conducting their own trials, assessments and analysis. In the latter 1980s and early 1990s it has been increasingly recognized that farmers should and could play a much greater part in agricultural research.

So field research on farming systems can be seen to have contributed especially to the appreciation and understanding of:

- the complexity, diversity and risk-proneness of many farming systems;

- the knowledge, professionalism and rationality

of small and poor farmers;

- their experimental mindset and behavior;

— their ability to conduct their own analyses.

\section{(e) Rapid rural appraisal}

The philosophy, approaches and methods known as rapid rural appraisal (RRA) began to emerge in the late 1970s. Workshops held at the Institute of 
Development Studies at the University of Sussex on rural development tourism (1977), indigenous technical knowledge (1978), and RRA itself $(1978,1979)$ were only some among the parallel moves in different parts of the world in search of better ways for outsiders to learn about rural life and conditions. RRA can be seen to have had three main origins.

The first was dissatisfaction with the biases, especially the anti-poverty biases, of rural development tourism - the phenomenon of the brief rural visit by the urban-based professional. These biases were recognized as spatial (visits near cities, on roadsides, and to the centers of villages to the neglect of peripheries); project (where projects were being undertaken, often with special official attention and support); person (meeting men more than women, elites more than the poor, the users more than the nonusers of services, and so on); seasonal (going in the dry and cool rather than hot and wet seasons which are often worse for poor rural people); and diplomatic (where the outsider does not wish to cause offense by asking to meet poor people or see bad conditions). All these could combine to hide the worst poverty and deprivation.

The second origin of RRA was disillusion with the normal processes of questionnaire surveys and their results. Again and again, over many years and in many places (see e.g., Moris, 1970; Campbell, Shrestha and Stone, 1979) the experience had been that large-scale surveys with long questionnaires tended to be drawnout, tedious, a headache to administer, a nightmare to process and write up, inaccurate and unreliable in data obtained, leading to reports, if any, which were long, late, boring, misleading, difficult to use, and anyway ignored.

The third origin was more positive. More costeffective methods of learning were sought. This was helped by the growing recognition by development professionals of the obvious fact that rural people were themselves knowledgeable on many subjects which touched their lives. What became known as indigenous technical knowledge (ITK) (IDS, 1979; Brokensha, Warren and Werner, 1980) was then increasingly seen to have richness and value for practical purposes. One major question, as it seemed then, was how more effectively to tap ITK as a source of information for analysis and use by outsider professionals.

In the late 1970 s, though, most of those professionals who were inventing and using methods which were quicker and more cost-effective than "respectable" questionnaire surveys, were reluctant to write about what they did, fearing for their professional credibility. They felt compelled to conform to standard statistical norms, however costly and crude their applications, and obliged in their reports and publications to use conventional methods, categories and measures. In a classic statement, Michael Collinson (1981) described how he would take only a week to conduct an exploratory survey to identify agricultural research priorities, but would then feel obliged to follow this with a formal verification survey which represented the major commitment of professional time and funds. This more costly exercise had always confirmed the exploratory survey but "the numbers which this formal survey provide are the only hard evidence produced by the diagnostic process. This is extremely important in convincing "the Establishment' ..." (Collinson, 1981, p. 444). To convince, the researcher had to be conservative; but the process was costly and decisions and action were delayed.

In the 1980 s, in some places, this situation was transformed. The family of approaches and methods known as Rapid Rural Appraisal (RRA) gained increasing acceptance. It began to be seen that it had its own principles and rigor (Chambers, 1980; Belshaw, 1981; Carruthers and Chambers, 1981). In the early 1980s, RRA was argued to be cost-effective, especially for gaining timely information, but still with some sense that it might only be a second-best. But by the mid-1980s, the RRA approaches and methods, when properly conducted, were more and more eliciting a range and quality of information and insights inaccessible through more traditional methods. Except when rushed and unself-critical, RRA came out better by criteria of cost-effectiveness, validity and reliability when it was compared with more conventional methods. In many contexts and for many purposes, RRA, when well done, showed itself to be not second-best but best.

In establishing the methods and principles of RRA many people and institutions took part. No account can do justice to them, and with imperfect knowledge there is no avoiding significant omissions. An earlier attempt to list countries where RRA had been developed identified 12 in Africa, eight in South and Southeast Asia, three in Latin America, three in Australasia and the Pacific, and one in Europe. Perhaps more than any other movement, agroecosystem analysis in Southeast Asia introduced new methods and established new credibility. In the mid-1980s, the University of Khon Kaen in Thailand was world leader in developing theory and methods, especially for multidisciplinary teams, and in institutionalizing RRA as a part of professional training. The International Conference on Rapid Rural Appraisal held at the University of Khon Kaen in 1985, and the published volume of papers which resulted (KKU, 1987), were landmarks. The practical value of RRA was confirmed, and its underlying theory outlined (Beebe, 1987; Gibbs, 1987; Grandstaff and Grandstaff, 1987a; Jamieson, 1987). In the latter 1980s, RRA continued to spread, and was adopted not only in tropical countries but also Australia (Ampt and Ison, 1989; Dunn and McMillan, 1991). RRA was further developed and disseminated through extensive 
training by the International Institute for Environment and Development (IIED) based in London, working with colleagues mainly in Africa and Asia, and through its publications, especially the informal periodical RRA Notes (1988-).

In specialized fields, too, there were parallel and overlapping developments. In health and nutrition, for example, Rapid Assessment Procedures (RAP) (Scrimshaw and Hurtado, 1987) were practised in at least 20 countries. In agriculture, some practitioners of farming systems research and extension innovated with lighter, quicker methods in an RRA style. In irrigation, a small literature built up on RRA (e.g., Potten, 1985; Groenfeldt, 1989). Moreover, "hard" journals published papers on RRA.

RRA began and continues as a better way for outsiders to learn. In answering the question - whose knowledge counts? - it sought, and continues to seek, to enable outsiders to gain information and insight from local people and about local conditions, and to do this in a more cost-effective and timely manner. It was, and remains, less one-sided than questionnaire surveys where much of respondents' time is taken by the outsider, and little or nothing is given back. All the same, like most past farming systems research, its normal mode entails outsiders collecting data, which they then take away to be analyzed elsewhere. This is a valid and useful activity and it has and will continue to have its place. Depending on one's point of view and the context, the normal practice of this nonparticipatory RRA can be described as extractive, or, more neutrally, elicitive.

\section{FROM RRA TO PRA}

In the mid-1980s, the words "participation" and "participatory" entered the RRA vocabulary. They already had a long history in rural development. To take but two examples, for some years in the 1970s and early 1980s, under the leadership of Norman Uphoff and others, Cornell University published the Rural Development Participation Review until US Agency for International Development (USAID) terminated its support, perhaps because the review was ahead of its time; and participation was a recurrent theme in the contributions to Michael Cernea's book, edited for the World Bank, Putting People First (1985, second edition 1991) which drew on experience from earlier years. It was at the 1985 Khon Kaen International Conference that the word participatory began, albeit modestly, to be used in connection with RRA. Discussions at the Conference generated a typology of seven types of RRA (KKU, 1987, p. 17) of which "participatory RRA" was one. For this, the dominant purpose was seen as stimulating community awareness, with the outsider's role as catalyst. Later, in 1988, participatory RRAs were listed by the IIED team as one of four classes of RRA methodologies the others being exploratory RRAs, topical RRAs, and monitoring RRAs (McCracken, Pretty and Conway, 1988).

In 1988, there were parallel developments in Kenya and India. In Kenya, the National Environment Secretariat, in association with Clark University, conducted an RRA in Mbusanyi, a community in Machakos District which led to the adoption in September of a Village Resource Management Plan (Kabutha and Ford, 1988). This was subsequently described as a Participatory Rural Appraisal, and the method outlined in two Handbooks (PID and NES, 1989; NES, 1990). Around the same time in 1988, the Aga Khan Rural Support Programme (India) (AKRSP) was interested in developing participatory RRA, and invited IIED to help. Jennifer McCracken carried out a four-week consultancy with AKRSP in Gujarat in September and October 1988 during which participatory rapid rural appraisals were conducted by and with villagers and AKRSP staff in two villages (McCracken, 1988). In different ways, both the Kenya and Indian experiences were seminal for understanding and for the development of PRA.

Subsequently, there was an explosion of innovation in India (for which see Mascarenhas et al. 1991) mainly in the nongovernment organization (NGO) sector $^{1}$ but also in some government organizations. MYRADA, based in Bangalore, trained its senior staff in PRA in early 1990 (Ramachandran, 1990), came to play a role in training for other NGOs and for government, and started a series of papers (PALM Series 1 -). AKRSP continued to innovate and broke new ground in showing how well village volunteers could themselves be facilitators of PRA. ActionAid, Bangalore undertook a networking role.

Among others, government organizations in India that received and promoted training included the Drylands Development Board, Karnataka, the District Rural Development Agencies, Andhra Pradesh, and several Forestry Departments. PRA methods were adopted by the National Academy of Administration, Mussoorie for the fieldwork of its 300-odd Indian Administrative Service probationers each year, and by the Xavier Institute of Social Services, Ranchi, which introduced PRA for the fieldwork of its students. The first book about PRA was written by Neela Mukherjee, working at the National Academy of Administration, and published in 1993.

At the same time, crossfertilization and spread took place internationally. ${ }^{2}$ The small group of the Sustainable Agriculture Programme at IIED, with support from the Ford Foundation and SIDA, was decisively influential through its activities in Africa and Asia, and spread PRA and its methods through 30 substantial field-based training workshops in 15 countries and through publications and papers, especially RRA Notes. They and others wrote source books and 
manuals (e.g., McCracken, Pretty and Conway, 1988; Gueye and Freudenberger, 1990, 1991; Theis and Grady, 1991).

Much of the spread was South-South, through sharing field experiences and training. PRA methods spread from India to Nepal on the initiative of Winrock International and to Sri Lanka on the initiative of Intercooperation. The World Resources Institute was active in Latin America. Two international field workshops were held in India: in 1992, ActionAid, AKRSP and MYRADA were hosts to 14 people from 11 countries in the South, and in 1992 ActionAid and OUTREACH (Bangalore) were hosts to 18 people, again from 11 countries. PRA or PRAtype activities continued to evolve independently in many places. In 1993 alone, the countries in which there was South-South sharing of experience included Botswana, China, Ethiopia, Ghana, India, Indonesia, Namibia, Nepal, the Philippines, South Africa, Tanzania, Uganda, Vietnam, Zambia, Zimbabwe and several countries in francophone West Africa. And PRA approaches and methods were also spreading to the industrialized world, with trainers from the South helping to initiate Northerners into PRA in Canada, Norway, Sweden, Switzerland and the United Kingdom.

A summary comparison of what are normally described as RRA and PRA is given in Table 1.

\section{RRA AND PRA: LABELS AND MEANINGS}

The question has been raised as to whether it is useful to define PRA as separate from RRA.

One view is that labels do not matter. There is a plethora of labels for approaches and methods of learning about rural life and conditions. Many of the sets of practices overlap. There is continuous innovation, sharing and exchange. In this view, the only importance of a label is the sense of pride of ownership and originality which it gives, so strengthening commitment, enthusiasm and good work among its practitioners. Otherwise, there would be no point in defining an exclusive territory of activities for PRA or any other set of approaches or methods.

An alternative view is that careful use of terms can help to maintain and improve quality, both by setting minimum standards for "good" RRA or PRA, and by distinguishing them from each other. The label of RRA has already been used quite widely to legitimate rushed rural development tourism, and unself-critical investigations: see for example, Pottier's critique (1992) of a quick but heavily biased "RRA" survey in Zambia, and some of the observations in a wide-ranging review (van Steijn, 1991) of RRA activities in the Philippines. The label of PRA has similarly been used to legitimate either bad work or to describe RRA; PRA has been used to describe data collection which is elicitive or extractive rather than participatory. In this view, then, it makes sense to separate out definitions of RRA as a form of data collection by outsiders who then take it away and analyze it; and of PRA as more participatory and empowering, meaning that outsiders are convenors, catalysts and facilitators who enable people undertake and share their own investigations and analysis.

A balanced view may be that since we are concerned here with static terms - RRA and PRA - for combinations and fluxes of activities which are dynamic and evolving and which take different forms in different places, labels can help to define what belongs where. There can, then, be a distinction between "an RRA" and "a PRA". An RRA is intended for learning by outsiders. A PRA is intended to enable local people to conduct their own analysis, and often to plan and take action. In this sense, PRA often implies radical personal and institutional change, and it would debase the term to use it for anything less than

Table 1. RRA and PRA compared

\begin{tabular}{lll}
\hline & RRA & PRA \\
\hline Period of major development & Late 1970s, 1980s & Late 1980s, 1990s \\
Major innovators based in & Universities & NGOs \\
Main users at first & Aid agencies & NGOs \\
Key resource earlier undervalued & Universities & Government field organizations \\
Main innovations & Local people's knowledge & Local people's analytical capabilities \\
& Methods & Behavior \\
Predominant mode & Team management & Experiential training \\
Ideal objectives & Elicitive, Extractive & Facilitating, Participatory \\
Longer term outcomes & Learning by outsiders & Empowerment of local people \\
\hline
\end{tabular}


Table 2. The RRA-PRA continuum

\begin{tabular}{|c|c|}
\hline Nature of process & RRAT \\
\hline Mode & empowering \\
\hline Outsiders' role & Investigator - \\
\hline $\begin{array}{l}\text { Information owned, analyzed } \\
\text { and used by }\end{array}$ & Outsiders \\
\hline Methods used & Mainly RRA plus sometimes PRA \\
\hline
\end{tabular}

this. The claim that "PRA is a simple methodology ..." (PID and NES, 1989, p. 1) is then misleading, since personal and institutional change are rarely simple or easy. Moreover, as PRA becomes increasingly fashionable, some may be tempted to label and relabel their work as PRA when it is still extractive rather than participatory, and when their behavior and attitudes are still dominant, top-down and unchanged.

The labels themselves have been questioned. It has been said of RRA that it need be neither rapid, nor rural, nor appraisal, but that otherwise it fits what it describes. Urban applications have proliferated, leading to the suggestion of PUA (participatory urban appraisal) or PLA (participatory local appraisal more inclusively, both rural and urban). With PRA, "participatory" has similarly been challenged, since "participation" can be used to mean people's participation in outsiders" projects, when much PRA has evolved to establish ownership of plans, actions and projects more with rural (or urban) people themselves. In addition, the processes which begin as appraisal now usually include analysis, and often lead on to planning, action, and participatory monitoring and evaluation, carrying the PRA label with them.

In practice there is a continuum between an RRA and a PKA, as illustrated in 'l'able 2.

RRA methods are more verbal, with outsiders more active, while PRA methods are more visual, with local people more active, but the methods are now largely shared. The major distinction is between an RRA (extractive-elicitive) approach where the main objective is data collection by outsiders, and a PRA (sharing-empowering) approach where the main objectives are variously investigation, analysis, learning, planning, action, monitoring and evaluation by insiders.

\section{THE MENU OF METHODS OF RRA AND PRA}

In its early days, RRA seemed to be largely organized common sense. During the $1980 \mathrm{~s}$, though, creative ingenuity was applied and more methods were borrowed, adapted and invented, many with a more participatory mode. Some of these were codified and written up in guidelines and manuals.

One view was that manuals of methods should be avoided; that the PRA principle of "use your own best judgement at all times" permitted and encouraged creativity; that manuals led to teaching and learning by rote, the ritual performance of methods for their own sake, and a loss of flexibility. Basic descriptions of methods (as in Mascarenhas, 1992) were considered enough. In early 1994, most of the leading PRA practitioners were working in this mode but a number of manuals, handbooks and sourcebooks had been compiled. ${ }^{3}$

A summary listing of headings can indicate some of the main modes and methods being used by early 1994. All the methods can be used in both RRA and PRA, but some are more emphasized in one than the other. RRA has tended to stress the use of secondary sources, verbal interaction especially through semistructured interviewing, and observation: so these are sometimes described as "RRA methods". For its part, a distinctive aspect of PRA has been the shared visual representations and analysis by local people, such as mapping or modeling on the ground or paper; estimating, scoring and ranking with seeds, stones, sticks or shapes; Venn diagramming; free listing and card sorting; linkage diagramming; and presentations for checking and validation: so these are often described as "PRA methods." A recent paper (Cornwall, Guijt and Welbourn 1993, p. 22) has usefully grouped methods under the three headings of visualized analyses; interviewing and sampling methods; and group and team dynamics methods. Since methods and sequences overlap, however, they are listed together here, using the categories and terms in common use:

- Secondary sources: such as files, reports, maps, aerial photographs, satellite imagery, articles and books;

- Semi-structured interviews. This has been regarded as the "core" of good RRA (Grandstaff and Grandstaff, 1987). It can entail having a mental or written checklist, but being open-ended and following upon the unexpected. Increasingly it is using participatory visual as well as traditional verbal methods;

- Key informants: enquiring who are the experts and seeking them out, sometimes through participatory social mapping;

- Groups of various kinds (casual; 
specialist/focus; deliberately structured; community/neighbourhood). Group interviews and activities are part of many of the methods;

- Do-it-yourself: asking to be taught, being taught, and performing village tasks - transplanting, weeding, ploughing, field-levelling, mudding huts, drawing water, collecting wood, washing clothes, stitching, thatching ...;

- They do it: villagers and village residents as investigators and researchers - women, poor people, school teachers, volunteers, students, farmers, village specialists. They do transects, observe, interview other villagers, analyse data, and present the results. This is a widespread element in PRA.

- Participatory analysis of secondary sources. The most common form is the analysis of aerial photographs (often best at 1:5000) to identify soil types, land conditions, land tenure etc (Dewees 1989; Mearns 1989; Sandford, 1989); satellite imagery has also been used (personal communication Sam Joseph);

- Participatory mapping and modeling, in which local people use the ground, floor or paper to make social, demographic, health, natural resource (soils, trees and forests, water resources etc), service and opportunity, or farm maps, or construct three-dimensional models of their land (Hahn, 1991; Mascarenhas and Kumar 1991);

- Transect walks - walking with or by local people through an area, observing, asking, listening, discussing, identifying different zones, soils, land uses, vegetation, crops, livestock, local and introduced technologies, etc; seeking problems, solutions and opportunities; and mapping and diagramming the zones, resources and findings (Mascarenhas, 1990); general types of transect walk include slope, combing, and loop. A seabottom transect has been conducted the Philippines (J. Mascarenhas, personal communication).

- Time lines and trend and change analysis: chronologies of events, listing major remembered events in a village with approximate dates; people's accounts of the past, of how things close to them have changed, ecological histories, changes in land use and cropping patterns, changes in customs and practices, changes and trends in population, migration, fuels used, education, health, credit and the causes of changes and trends, often in a participatory mode with estimation of relative magnitudes;

- Oral histories and ethno biographies: oral histories (Slim and Thompson, 1993), and local histories of, for example, a crop, an animal, a tree, a pest, a weed (Box, 1989);

- Seasonal calendars - by major season or by month to show seasonal changes such as days and distribution of rain, amount of rain or soil mois- ture, crops, agricultural labor, nonagricultural labor, diet, food consumption, types of sickness, prices, animal fodder, fuel, migration, income, expenditure, debt, etc;

- Daily time use analysis indicating relative amounts of time, degrees of drudgery etc of activities, sometimes indicating seasonal variations;

- Livelihood analysis - stability, crises and coping, relative income, expenditure, credit and debt, multiple activities, often by month or season;

- Participatory linkage diagramming — of linkages, flows, connections and causality;

- Institutional or "Chapati" or Venn diagramming - identifying individuals and institutions important in and for a community, or within an organisation, and their relationships (for examples see Guijt and Pretty, 1992);

- Well-being and wealth grouping and ranking - identifying groups or rankings of households according to wellbeing or wealth, including those considered poorest or worst off (Grandin, 1988; Swift and Umar, 1991; Mearns et al. 1992; RRA Notes, No. 15 passim); often leading to the identification of key indicators of well-being.

- Analysis of difference, especially by gender, social group, wealth/poverty, occupation and age. Identifying differences between groups, including their problems and preferences (Welbourn, 1991). This includes contrast comparisons - asking one group why another is different or does something different, and vice versa (Bilgi, 1992);

- Matrix scoring and ranking, especially using matrices and seeds to compare through scoring, for example different trees, or soils, or methods of soil and water conservation, or varieties of a crop (Drinkwater, 1993);

- Estimates and quantification, often using local measures, judgements and materials such as seeds, pellets, fruits, stones or sticks as counters, sometimes combined with participatory maps and models, matrices, card sorting and other methods;

- Key probes; questions which can lead direct to key issues such as - "What do you talk about when you are together?" "What new practices have you or others in this village experimented with in recent years?" "What vegetable, tree, crop, crop variety, type of animal, tool, equipment ... would you like to try out?" "What do you do when someone's hut or house burns down?";

- Stories, portraits and case studies such as a household history and profile, coping with a crisis, how a conflict was or was not resolved;

- Team contracts and interactions - contracts drawn up by teams with agreed norms of behavior; modes of interaction within teams, including changing pairs, evening discussions, mutual criticism and help; how to behave in the field, etc. (The 
team may be just outsiders, or a joint team with villagers);

- Presentation and analysis - where maps, models, diagrams, and findings are presented by local people, or by outsiders, and checked, corrected and discussed;

- Sequences: the use of methods in sequence for example participatory social mapping leading to the identification of key informants or analysts, or leading to the sequence: household lists wealth or well-being ranking or grouping - focus groups - matrix scoring and preference ranking. Sequences of analyses by experts on different stages of a process (e.g., men on ploughing, women on transplanting and weeding... ) etc;

- Participatory planning, budgetting, implementation and monitoring, in which local people prepare their own plans, budgets and schedules, take action, and monitor and evaluate progress;

- Group discussions and brainstorming, by local people alone, by focus groups of local people, by local people and outsiders together, or by outsiders alone;

- Short standard schedules or protocols either for very short and quick questionnaires, or to record data (e.g., census information from social mapping) in a standard and commensurable manner.

- Report writing without delay, either in the field before returning to office or headquarters, or by one or more people who are designated in advance to do this immediately on completion of an RRA or of a sequence of PRA activities.

\section{PRACIICAL APPLICATIONS}

RRA approaches and methods have been used for appraisal, analysis and research in many subject areas. These include agroecosystems; natural resources, including forestry, fisheries, wildlife management, and the environment; irrigation; technology and innovation; health and nutrition; farming systems research and extension; pastoralism; marketing; disaster relief (Slim and Mitchell, 1992); organizational assessment; social, cultural and economic conditions; and many special topics.

PRA approaches and methods have evolved and spread so fast that any inventory is likely to be incomplete. ${ }^{4}$ In early 1994 , most of the known applications can be separated into four types of process, and into four major sectors.

The four major types of process are:

- participatory appraisal and planning;

- participatory implementation, monitoring and evaluation of programs;

- topic investigations;

- training and orientation for outsiders and villagers.

The four major sectors are:

\section{(a) Natural resources management}

- Watersheds, and soil and water conservation: e.g., participatory watershed planning and management (Pretty, 1990; Kerr, 1991; Devavaram et al., 1991; Neefjes, et al. 1993; Shah, 1993);

- Land policy (Johannson and Hoben, 1992);

- Forestry, including: social and community forestry; degraded forest assessment, protection, nurseries and planting; identification of tree uses; and uses and marketing of forest products. (See e.g. Case, 1990; Inglis, 1991; Freudenthal and Narrowe, 1991; SPWD, 1992);

- Fisheries (McCracken, 1990; Mascarenhas and Hildalgo, 1992; Colaco and Bostock, 1993);

- biodiversity and wildlife reserve buffer zones (Kar, 1993);

- Village plans: preparing Village Resource Management Plans (PID and NES, 1989), Participatory Rural Appraisal and Planning (as developed by AKRSP - Shah, Bharadwaj and Ambastha, 1991a, 1991b, and others).

\section{(b) Agriculture}

- Farmer participatory research/farming systems research and problem identification and analysis by farmers (Ampt and Ison, 1988, 1989; Kar and Datta, 1991; Dunn and Macmillan 1991; FSRU, 1991; PRA Team, 1991; Guijt and Pretty, 1992; Lightfoot et al., 1992; Chambers, 1993; Drinkwater, 1993; Lightfoot and Noble, 1993);

- Livestock and animal husbandry (Leyland, 1993; Maranga, 1993; Sonaiya, 1993; Young, 1993; RRA Notes No. 20: Special Issue of Livestock, 1994);

- Irrigation, including rehabilitation of smallscale gravity flow irrigation systems (especially in Tamil Nadu);

- Markets: investigating markets and smallholder marketing potentials (Holtzman 1993)

\section{(c) Poverty and social programs}

- Credit: identification of credit needs, sources and interventions;

- Selection: finding and selecting poor people for a program, and deselecting the less poor (e.g., Chandramouli, 1991; RRA Notes 15, Pretty, Subramanian and Ananthakrishnan, 1992);

- Income-earning: identification of nonagricultural income-earning opportunities.

- Women and gender: participatory appraisal of problems and opportunities (Welbourn, 1991; Grady et al., 1991; The Women of Sangams, Pastapur and Pimbert, 1991; Tolley and Bentley, 
1992; Bilgi, 1992; Kar et al., 1992; Sheelu and Devaraj, 1992; Robinson, 1993);

- Adult literacy (ActionAid's pilot programs in Bangladesh, Uganda and El Salvador using PRA diagramming modules as a stepping stone to spelling (personal communication David Archer); - Participatory poverty assessments (as part of the World Bank-supported Country Poverty Assessments) in Ghana and Zambia, both initiated in 1993.

\section{(d) Health and food security}

- Health assessments and monitoring with applications including women's reproductive health (Tolley and Bentley, 1992; Cornwall, 1992), disease problem ranking (Welbourn, 1992), unemployment and health (Cresswell, 1992), identifying major illness, healthcare providers and costs (Joseph, 1992), and testing methods for establishing baselines and monitoring (Adams, Roy and Mahbub, 1993), planning health projects (Francis, Devavaram and Erskine, 1992); (see also Heaver, 1992 and RRA Notes 16, pp. 101-106 for a fuller listing of actual or potential uses).

- Food security and nutrition assessment and monitoring (Maxwell, 1989; Appleton, 1992; Buchanan-Smith et al., 1993; Lawrence Haddad personal communication)

- Water and sanitation assessment, planning and location (Narayan 1993)

These lists illustrate the main known applications. They are not comprehensive. A further application has been the appraisal of organizational cultures (Kievelitz and Reineke, 1993) and more applications can be expected.

\section{SPREAD AND IMPACT OF PRA}

For several reasons, there are still, in early 1994, few case studies of the impact of PRA as development process. First, PRA is recent, and many PRA processes are still in their early stages. Second, responding to demand and their own sense of priorities, experienced practitioners have been mostly engaged in training and appraisal rather than monitoring and evaluation, and this emphasis is reflected in the reports they have written. Third, in the first years of PRA, academic researchers were slow to recognize what was happening. These were conditions in which negative experiences were liable to be overlooked. In the mid-1990s more feedback is needed from failures, from those who have experienced PRA and not subsequently adopted it, and from organizations where attempts to introduce it have not been successful.
That said, evidence takes two main forms: first, the scale of adoption and use; and second, reports of practical use and evaluations.

First, the number of countries in which PRA appears strongly established and spreading is rising. Any listing will be based on incomplete knowledge, liable to error, and soon out of date. Early in 1994 such countries and regions include Bangladesh, Botswana, Burkina Faso, Ethiopia, Kenya, India, Mali, Nepal, Nigeria, Pakistan, the Philippines, Senegal, Sri Lanka, Uganda, Vietnam, and Zimbabwe, not to mention countries in Latin America. The number of organizations across a much larger number of countries which have to some degree adopted PRA is large and growing. Southern NGOs which are using PRA (mid-1993) number hundreds, while many Northern NGOs and International Agencies have now supported the spread of PRA. Universities were at first slow to recognize PRA or adopt PRA methods, but now tens of universities and training and research institutes have some staff who are exploring and using it. Government and parastatal organizations, all or parts of which have espoused PRA, are a similar number. Among these, a few have sought to introduce it throughout their programs on a national or statewide scale. These include the Soil and Water Conservation Branch of the Ministry of Agriculture in Kenya, which has officially adopted a PRA approach for its work in over 40 districts; the District Rural Development Agencies, Andhra Pradesh, India; and the Forest Departments of several Indian States. Government programs with donor support are introducing PRA training and approaches, as with IFAD-supported programs in Indonesia and Sri Lanka, the ODA-supported Western Ghats Environmental Programme in India, the SIDAsupported Vietnam-Sweden Forestry Cooperation Programme in Vietnam, and UNICEF-supported programs in India and Kenya.

Because the PRA label, and to a lesser extent its substance, appear in early 1994 to be spreading exponentially, the scale of applications is difficult to assess. In 1992, ActionAid Nepal completed participatory mapping in approximately 130 villages as a means of monitoring and evaluating the utilization of services (ActionAid, 1992). In 1993 ActionAid Pakistan completed wealth/well-being ranking with 38,000 people as a stage in identifying the poorer people (personal communication, Humera Malik). UNICEF, Lucknow, is reported to be planning one thousand PRA training sessions over the next five years.

Despite these examples, the actual spread and use of PRA in large field agencies, whether government or NGO, is easily overestimated to the extent that as PRA becomes "politically correct," so reports of PRA are likely to be inflated. Sometimes, too, resistance has occurred. Much depends on personal orientation and choice, and on rewards. In smaller organizations with 
committed leadership, adoption has often taken place quickly. In large organizations, it has not been by administrative fiat, but by consistent high-level support, widespread training of good quality, and appropriate systems of rewards, that actual (in contrast with apparent) spread has occurred. Despite the slow spread implied by these conditions, the number of people in large organizations who have now chosen to use PRA as approach and process, and not just PRA methods, probably runs into thousands, and is growing.

Second, reports of practical use are innumerable but scattered in a large, inaccessible grey literature; and in early 1994 evaluations are still few. Most reports have been positive. There are dangers of selective perception and reporting, but some reports (including those from IIED see e.g., Guijt, 1992) gain in credibility through self-critically presenting and discussing problems and errors.

By early 1994, the most systematic impact analysis of PRA compared with alternatives has been a participatory study conducted in Kenya in April-May 1993 (Pretty and Thompson, 1993). Six areas of the Catchment Approach Program of the Soil and Water Conservation Branch of the Ministry of Agriculture were studied. Performance indicators included maize yields, diversity of crops, reappearance of springs and/or increase in surface water flow, continuing activity by a catchment committee, and awareness and adoption in neighboring communities. The study showed that performance had been worst in a showcase catchment where the approach had not been participatory. The impact indicators were generally higher where catchment committees were freely elected, and where farmers had participated in planning and layout, and they were consistently best in the catchment where the program had begun with an interdepartmental PRA.

There remains a research agenda to understand better the applications and potentials of PRA, its processes and impacts, and its shortcomings and strengths.

\section{EXPLAINING OUR PAST IGNORANCE}

Any positive assessment is faced with a problem of explanation. If PRA approaches and methods are powerful and popular, the puzzle is why it has taken until the 1990 s for the methodological streams to come together and further evolve; for the menu of methods to reach its present range and versatility; and for the many actual and potential applications to become evident. At a personal level, fieldworkers now in their 50 s or 60 s can wonder how for decades they have been working in rural development without knowing about all this. More generally, it is a mystery why it has taken so long for the development community as a whole to "discover" in this way the richness not just of the knowledge of villagers, but of their creative and analytical abilities.

Much of the mystery disappears if explanation is sought not in local people, but in outsider professionals. For the beliefs, behavior and attitudes of most outsiders have been similar all over the world. Agricultural scientists, medical staff, teachers, officials, extension agents and others have believed that their knowledge was superior and that the knowledge of farmers and other local people was inferior; and that they could appraise and analyze but poor people could not. Many outsiders then either lectured, holding sticks and wagging fingers, or interviewed impatiently, shooting rapid fire questions, interrupting, and not listening to more than immediate replies, if that. Outsiders' reality blanketed that of local people. They "put down" the poor. Outsiders' beliefs, demeanor, behavior and attitudes were then self-validating. Treated as incapable, poor people behaved as incapable, reflecting the beliefs of the powerful, and hiding their capabilities even from themselves. Nor did many outsider professionals know how to enable local people to express, share and extend their knowledge. The ignorance and inabilities of rural people were then not just an illusion; they were an artifact of outsiders' behavior and attitudes, of their arrogant and ignorant manner of interacting with local people.

For participatory approaches and methods to take off, a stage had also to be reached when different conditions could come together: recognition of past error and inadequacy, as has occurred with much agricultural research for resource-poor farmers; greater confidence and professionalism in rural NGOs; the invention of approaches such as agroecosystem analysis which simply did not exist before the 1980s; and the emergence of an international community of communication. This has required a critical mass and momentum in which approaches and methods could be shared between disciplines, countries, and organizations, as for RRA at the Institute of Development Studies at the University of Sussex in 1979 and at Khon Kaen University in 1985 (KKU, 1987), and as for PRA at Bangalore in 1991 (Mascarenhas et al. 1991). The most important element of all has been the insight that in facilitating PRA the behavior and attitudes of outsiders matter more than the methods and their correct performance. Perhaps then it is understandable that it has taken so long for these participatory approaches and methods, in their many forms and with their many labels, to evolve, cluster and coalesce, and to spread, as philosophy, repertoire and practice. Perhaps, in the 1990s, their time has come. 


\section{NOTES}

1. Any listing of the NGOs that pioneered at an early stage in India would include (in alphabetical order) ActionAid, Bangalore; Activists for Social Alternatives, Trichy; the Aga Khan Rural Support Programme (India); Krishi Gram Vikas Kendra, Ranchi; MYRADA, Bangalore; Seva Bharati, Midnapore District; SPEECH, Madurai; and Youth for Action, Hyderabad.

2. Among international foundations, agencies and NGOs active in supporting and promoting PRA at an early stage were the Ford Foundation (in India, Bangladesh and East Africa), Winrock International (in Nepal), Intercooperation (Berne and in Sri Lanka), the Overseas Development Administration (UK), ActionAid (London and in South Asia, West Africa and elsewhere), the Aga Khan Foundation (in India), the Near East Foundation and the Centre for Development Services (Cairo and the Middle East), the World Resources Institute (Washington and Latin America), and in various countries CARE, Save the Children, OXFAM, UNICEF and World Neighbours; while others including GTZ, IDRC, IFAD, NOVIB, the Paul Hamlyn Foundation, SAREC, SDC and SIDA provided support.

3. Several manuals, guides and handbooks have, however, been compiled. In addition to a number on RRA, others have used a PRA label or have been in a PRA tradition. In English these include a step-by-step manual Participatory Rural Appraisal Handbook (NES et al., 1990) based on early PRAs in Kenya: Participatory Rapid Appraisal for Community Development (Theis and Grady, 1991) based on experiences in the Middle East and North Africa; an illustrated guide PRA for Nepal: Concepts and Methods (Campbell and Gill, 1991); a two-volume Field Methods Manual including methods and applications of PRA for Joint Forest Management in India (SPWD, 1992); a resource manual of papers for trainers and practitioncrs of PRA (Lcurs, 1993); a manual for productivity systems assessment and planning in the Philippines (Dilig, 1993); A Handbook for
PRA Practitioners, based on PRA training in South Africa (Participants in Bulwer Workshop, 1993); An Introduction to Rapid and Participatory Rural Appraisal in BRAC (Howes, 1993); and Rapid Appraisal Methods for Coastal Communities (Townsley, 1993). Others have been published and made available in French (Gueye and Freudenberger, 1990, 1991), Spanish (Rietbergen-McCracken, 1991), and German (Schönhuth and Kievelitz, 1993); and in early 1994 the International Institute for Environment and Development (IIED), London is in the late stages of preparing several source books for PRA methods and training.

4. To document the applications of RRA and PRA to date (early 1994) would require a separate full paper and bibliography. For accessible sources on RRA see Agricultural Administration, 1981; Longhurst, 1981; KKU, 1987, especially Gibbs, 1987, and the bibliography; and Lovelace, Subhadhira and Simaraks, 1988. For recent accessible sources on PRA see publications of the Sustainable Agriculture Programme of the International Institute for Environment and Development ( 3 Endsleigh Street, London WC1H 0DD) including cases from Cape Verde, Chile, Ecuador, Ethiopia, Fiji, the Gambia, India, Indonesia, Kenya, Pakistan, Sri Lanka, Sudan, and Zimbabwe; RRA Notes 1988 , passim, especially Number 13 reporting experience in India; PALM Series; Forests, Trees and People Newsletter Number 15/16, 1992; Leurs, 1993; and OUTREACH (1993-). Separate annotated bibliographies on RRA/PRA concerning agriculture, food security, forestry, gender, health, industrial country applications, irrigation, livestock and pastoralism, monitoring and evaluation, PRA methods, soil and water conservation, training, urban applications, and other sectors are in preparation at the Institute of Development Studies, University of Sussex, Brighton BN] 9RE, UK. A computerized data base of over 1,000 items on RRA and PRA at IDS and IIED has been compiled. In early 1994, unpublished sources on PRA experiences number several hundreds.

\section{REFERENCES}

ActionAid, Participatory Rural Appraisal: Utilization Survey Report, Part I Rural Development Area, Singhupaichowk, Monitoring and Evaluation Unit (Kathmandu: ActionAid, 1992).

Adams, Alayne, Rita Das Roy and Amina Mahbub "Participatory methods to assess change in health and women's lives; An exploratory study for the BRACICDDR,B Joint Project in Matlab" (Cambridge, MA: Harvard Center for Population and Development Studies, September (993).

Ampt, P. R., and R. L. Ison, "Rapid rural appraisal for the identification of grassland research problems," Proceedings of the XVI International Grassland Congress (Nice, France: 1989), pp.1291-1292.

Ampt, P., and R. Ison, "Report of a rapid rural appraisal to identify problems and opportunities for agronomic research and development in the Forbes Shire, NSW" (Sidney: School of Crop Sciences, University of Sydney, December 1988).
Appleton, Judith, "Notes from a food and nutrition PRA in a Guinean fishing village," RRA Notes, No. 16 (1992), pp. $77-85$.

Ashby, J. A., Evaluating Technology with Farmers: A Handbook (Cali, Colombia, CIAT, December 1990).

Beebe, J., "Rapid appraisal: The evolution of the concept and the definition of issues," in KKU, Proceedings of the 1985 International Conference on Rapid Rural Appraisal (Khon Kaen, Thailand: University of Khon Kaen, 1987), pp, 47-68.

Belshaw, D., "A theoretical framework for data-economizing appraisal procedures with applications for rural development planning," in R. Longhurst (Ed.), IIDS Bulletin, Vol. 12, No. 4 (1981), pp. 12-22.

Bentley, Margaret E., Gretel H. Pelto, Walter L. Straus, Debra A. Schumann, Catherine Adegbola, Emanuela de la Pena, Gbolahan A. Oni, Kenneth H. Brown and Sandra L. Huffman, "Rapid ethnographic assessment: Applications in a diarrhea management program," Social 
Science in Medicine, Vol. 27, No. 1 (1988), pp.107116.

Biggs, S., "Informal R and D," Ceres, Vol. 13, No. 4 (1980), pp. 23-26.

Bilgi, Meena, Unpublished correspondence on analysis of women's time use by men, available from Helen McLaren, IDS, University of Sussex, Brighton BN1 9RE, UK (1992).

Box, Louk, "Virgilio's Theorem: A method for adaptive agricultural research," in R. Chambers, A. Pacey and L. Thrupp (Eds.), Farmer First (London: IT Publications 1989), pp. 61-67.

BRAC, The Net: Power Structure in Ten Villages (Dhaka: Bangladesh Rural Advancement Committee, 1983).

Brokensha, David W., D. M. Warren, and O. Werner, Indigenous Knowledge Systems and Development, (Lanham, MD: University Press of America, 1980).

Buchanan-Smith, M. et al., "Finding out how people prioritise their food security problems in Chad: The challenges of RRA at national level," RRA Notes, No. 18 (1993), pp. 33-43.

Bunchl, R., Two Ears of Corn: A Guide to People-Centered Agricultural Improvement (Oklahoma City: World Neighbors, 1985).

Camphell, G. J., R. Shrestha and L. Stone, The Use and Misuse of Social Science Research in Nepal (Kirtipur, Kathmandu: Research Centre for Nepal and Asian Studies, Tribhuvan University, 1979).

Campbell, Lorna, and Gerard J. Gill, PRA for Nepal: Concepts and Methods, Research Support Series Number 4 (Kathmandu: HMG Ministry of AgricultureWinrock International, February 1991).

Carruthers, Ian, and Robert Chambers, "Rapid appraisal for rural development," Agricultural Administration, Vol. 8, No. 6 (1981), pp. 407-422.

Case, D'Arcy Davis, The Community's Toolbox: The Idea, Methods and Tools for Participatory Assessment, Monitoring and Evaluation in Community Forestry, Community Forestry Field Manual 2 (Rome: FAO, 1990).

Cernea, Michael (Ed.), Putting People First: Sociological Variables in Development Projects (Baltimore: The Johns Hopkins Press, 1985, second edition 1991).

Chambers, Robert, "Rapid rural appraisal: Rationale and repertoire," IDS Discussion Paper (Brighton) (No. 155. September 1980).

Chambers, Robert, Arnold Pacey and Lori Ann Thrupp (Eds), Farmer First: Farmer Innovation and Agricultural Research (London: Intermediate Technology Publications, 1989).

Chambers, Robert, "Methods for analysis by farmers: The professional challenge," Journal for Farming Systems Research/Extension, Vol. 4, No. 1 (1993), pp. 87-101.

Chandramouli, K., "Pass on the pen" approach: Identifying the poorest of the poor families," RRA Notes, No. 14. (1991), pp. 29-32.

Colaco, Peter, and Tim Bostock, "Post-harvest goes participatory: Participating and learning in a fishing village," Bay of Bengal News (September 1993), pp. 6-11.

Collinson, M., "A low cost approach to understanding small farmers," Agricultural Administration, Vol. 8, No. 6 (1981), pp. 433-450.

Convergence (various issues and special issues).

Conway, G., "Rapid rural appraisal and agroecosystem analysis: A case study from Northern Pakistan," in KKU, Proceedings of the 1985 International Conference on Rapid Rural Appraisal (Khon Kaen, Thailand: University of Khon Kaen, 1987), pp. 228-254.

Conway, G., Agroecosystem Analysis for Research and Development, (Bangkok: Winrock International, 1986).

Conway, G., "Agroecosystem analysis", Agricultural Administration, Vol. 20 (1985), pp. 31-55.

Cornwall, Andrea, "Body mapping in health RRA/PRA," RRA Notes, No.16 (1992), pp. 69-76.

Comwall, Andrea, Irene Guijt and Alice Welbourn, "Acknowledging process: Challenges for agricultural research and extension methodology," Discussion Paper 333 (Brighton: Institute of Development Studies December, 1993).

Cresswell, Teresa, "Unemployment and health: The development of the use of PRA in identified communities in Staveley, North Derbyshire," RRA Notes, No. 16 (1992), pp. $27-30$

Daniels, P. W., S. Holden, E. Lewin, and Sri Dadi (Eds), Livestock Services for Smallholders, Proceedings of an International Seminar held in Yogyakarta, Indonesia November 15-16 1992 (Bogor, Indonesia: Indonesia International Animal Science, Research and Development Foundation, 1993).

Dewees, Peter, "Aerial photography and household studies in Kenya," RRA Notes No.7 (1989), pp. 9-12.

Devavaram, John, Nalini J. Vimalnathan, Abdul Sarkar, Krishnan, A. P. Mayandi and Karunanidhi, "PRA for rural resource management," RRA Notes, No. 13 (1991), pp. 102-111.

Dilig, Rutcheli A Manual on the Estate/Barangay-level Productivity Systems Assessment and Planning (PSAP) Methodolngy, published for the Tripartite Partnership for Agrarian Reform and Rural Development (Quezon City, Philippines: Phil DHRRA, September 1993).

Drinkwater, Michael, "Sorting fact from opinion: The use of a direct matrix to evaluate finger millet varieties," $R R A$ Notes, No.17 (1993), pp. 24-28.

Dunn, Tony and Allan McMillan, "Action research: The application of rapid rural appraisal to learn about issues of concern in landcare areas near Wagga Wagga, NSW," Paper presented to a conference on Agriculture, Education and Information Transfer, Murrumbigee College of Agriculture (New South Wales: September 30-October 2 1991).

Farrington, John (Ed.), Experimental Agriculture, Vol.24, Part 3 (1988).

Farrington, John, and Adrienne Martin, "Farmer participation in agricultural research: A review of concepts and practices," Agricultural Administration Occasional Paper, No. 9 (London: ODI, 1988).

Forests, Trees and People Newsletter (International Rural Development Center, Box 7005. S-750-07 Uppsala, Sweden).

Francis, Sheelu, John Devavaram and Arunothayam Erskine, "Training workshop on participatory rural appraisal for planning health projects," RRA Notes, No.16 (1992), pp. $37-47$.

Freire, Paulo, Pedagogy of the Oppressed (New York: The Seabury Press, 1968).

Freudenthal, K. and Narrowe, Focus on People and Trees: a guide to designing and conducting community baseline 
studies for community forestry, Report No. 20, Development Studies Unit, Department of Social Anthropology (Stockholm: Stockholm University, 1991).

FSRU, Structural Adjustment and Communal Area Agriculture in Zimbabwe: Case Studies from Mangwende and Chivi Communal Areas: A Report of a Rapid Rural Appraisal Exercise, Farming systems Research Unit, Department of Research and Specialist Services, Ministry of Lands, Agriculture and Rural Settlement (Harare, Zimbabwe: Ministry of Lands, November 1991).

FSSP, Diagnosis, Design and Analysis in Farming Systems Research and Extension, Volumes I, II and III, and Trainer's Manual (Gainesville, FL: Farming Systems Support Project, Institute of Food and Agricultural Sciences, University of Florida, December 1987).

Gaventa, John, and Helen Lewis, Participatory Education and Grassroots Development: The Case of Rural Appalachia, Gatekeeper Series 25 (London: IIED, 1991).

Gibbs, Christopher, "Rapid rural appraisal: An over view of concepts and applications," in KKU, Proceedings of the 1985 International Conference on Rapid Rural Appraisal (Khon Kaen, Thailand: University of Khon Kaen, 1987), pp. 193-206.

Gilbert, E. H., D. W. Norman and F. E. Winch, Farming Systems Research: A Critical Appraisal, MSU Rural Development Paper No. 6, Department of Agricultural Economics (East Lansing: Michigan State University, 1980).

Grady, H., et al., "Assessing women's needs in Gaza using participatory rapid appraisal techniques," RRA Notes, No.10 (February 1991), pp. 12-19.

Grandin, Barbara, Wealth Ranking in Smallholder Communities: A Field Manual (London: Intermediate Technology Publications, 1988).

Grandstaff, Terry B., and Somluckrat W. Grandstaff, "A conceptual basis for methodological development in rapid nural appraisal," in KKU, Proceedings of the 1985 International Conference on Rapid Rural Appraisal (Khon Kaen, Thailand: University of Khon Kaen, 1987), pp. 69-88.

Grandstaff, Somluckrat W., and Terry B. Grandstaff, "Semistructured interviewing by multidisciplinary teams in RRA," in KKU, Proceedings of the 1985 International Conference on Rapid Rural Appraisal (Khon Kaen, Thailand: University of Khon Kaen, 1987), pp. 129-143.

Groenfeldt, D., Guidelines for Rapid Assessment of Minor Irrigation Systems in Sri Lanka, Working Paper No. 14 (Colombo, Sri Lanka: International Irrigation Management Institute, 1989).

Gueye, Bara and Karen Schoonmaker Freudenberger, Méthode Accélerée de Recherche Participative (London: IIED, August 1991).

Gueye, Bara, and Karen Schoonmaker Freudenberger, Introduction à la Méthode Accélerée de Recherche Participative (MARP) (Dakar, Senegal: Centre de Recherches pour le Développement International, October 1990).

Guijt, Irene (Ed.), From Input to Impact: Participatory Rural Appraisal for ActionAid the Gambia (London: IIED, 1992).

Guijt, Irene, and Jules N. Pretty (Eds.), Participatory Rural Appraisal for Farmer Participatory Research in Punjab, Pakistan (London: IIED, September 1992).

Gypmantasiri et $a l$, and Gordon Conway, An
Interdisciplinary Perspective of Cropping Systems in the Chiang Mai Valley: Key Questions for Research (Chiang Mai, Thailand: Multiple Cropping Project, Faculty of Agriculture, University of Chiang Mai, June 1980).

Hahn, H., Apprendre avec les yeux, s'exprimer avec les mains: des paysans se forment à la gestion du terroir, (Langenbruck, Switzerland: AGRECOL, 1991).

Harwood, R., Small Farm Development: Understanding and Improving Farming Systems in the Humid Tropics (Boulder, CO: Westview Press, 1979).

Heaver, Richard, "Participatory rural appraisal: Potential applications in family planning, health and nutrition programmes," RRA Notes, No. 16 (1992), pp. 13-21.

Holtzman, John S., "Rapid appraisal methods in a diagnostic assessment of vegetable seed marketing," in Krishna Kumar (Ed.), Rapid Appraisal Methods (Washington, DC: The World Bank, 1993), pp. 112-135.

Howes, Mick, An Introduction to Rapid and Participatory Rural Appraisal (Brighton: Institute of Development Studies, University of Sussex, October 1993).

IDS, "Whose knowledge counts?," IDS Bulletin, Vol. 10, No. 2 (1979).

Inglis, Andrew Stewart, "Harvesting local forestry knowledge: A comparison of RRA and conventional surveys," RRA Notes, No. 12 (1991), pp. 32-40.

Jamieson, N., "The paradigmatic significance of RRA," KKU, Proceedings of the 1985 International Conference on Rapid Rural Appraisal (Khon Kaen, Thailand: University of Khon Kaen, 1987), pp. 89-102.

Johansson, Lars, and Allan Hoben, "RRA's for land policy formulation in Tanzania," Forests, Trees and People Newsletter, No. 14/15 (February 1992), pp. 26-31.

Joseph, S., "Participatory rural appraisal in identifying major illness, healthcare providers and costs," RRA Notes, No. 16 (1992), pp. 53-56.

Kabutha, Charity, and Richard Ford, "Using RRA to formulate a village resources management plan, Mbusyani, Kenya," RRA Notes, No. 2 (October 1988), pp. 4-11.

Kar, Kamal, "Participatory rural appraisal for understanding the man-environment conflict and its impact on the loss of bio-diversity of wetlands ecosystem at Bhitarkanika Mangrove area in Orissa," (Seva Bharati, Kapgari, Midnapore District, West Bengal, India: 1993).

Kar, Kamal, D. C. Banerjee, Manjushree Kaviraj and Sumit N. Datta, Participatory Rural Appraisal for, Development of Women and Children in Rural Areas, 'Document of efforts of village women of Bhagawampur, district Hooghly, West Bengal, India, in planning their community services (Seva Bharati, India: 1992).

Kar, Kamal, and Sumit N. Datta, Participatory Rural Appraisal for Development of Rainfed Areas, Report of July 1991 training workshop (Seva Bharati, India: 1991).

Kassam, Yusuf, and Kemal Mustafa (Eds.), Participatory Research: An Emerging Alternative Methodology in Social Science Research (New Delhi: Society for Participatory Research in Asia, 1982).

Kerr, J. M. (Ed)., Farmers' Practices and Soil and Water Conservation Programmes, Summary proceedings of a workshop, June 19-21 1991, ICRISAT Center (Patancheru, India: 1991).

Kievelitz, Uwe, and Rolf-Dieter Reineke, "Rapid appraisal of organisational cultures: A challenge for field work," RRA Notes, No. 17 (March 1993), pp. 57-63. 
KKU, Proceedings of the 1985 International Conference on Rapid Rural Appraisal (Khon Kaen, Thailand: Rural Systems Research and Farming Systems Research Projects, University of Khon Kaen, 1987).

Kumar, Krishna (Ed.), Rapid Appraisal Methods (Washington: The World Bank, 1993).

Leurs, Robert, A Resource Manual for Trainers and Practitioners of Participatory Rural Appraisal (PRA), Papers in the Administration of Development No. 49, Development Administration Group, Institute of Local Government Studies, University of Birmingham (Birmingham: March 1993).

Leyland, Tim, "Participatory rural appraisal in Afghanistan," in P. W. Daniels et al. (Eds.), Livestock Services for Smallholders (Bogor, Indonesia: Indonesian International Animal Science Research and Development Foundation, 1993).

Lightfoot, C., and D. Minnick, "Farmer-first qualitative methods: Farmers' diagrams for improving methods of experimental design in integrated farming systems," Journal for Farming Systems Research-Extension, Vol. 2, No. 1 (1991), pp. 57-71.

Lightfoot, Clive, and Reg Noble, "A participatory experiment in sustainable agriculture," Journal for Farming Systems Research/Extension, Vol. 4, No. 1 (1993), pp. 11-34.

Lightfoot, C., R. Noble and R. Morales, Training Resource Book on a Participatory Method for Modelling Bioresource Flows, ICLARM Educational Series (Manila: International Center for Living Aquatic Resources Management, 1991).

Lightfoot, C., P. Dalgaard, M. Bimbao and F. Fermin, "Farmer participatory procedures for managing and monitoring sustainable farming systems," Paper presented at the Second Asian Farming Systems Symposium, BMICH (Colombo, Sri Lanka: November 1992).

Longhurst, R. (Ed.), Rapid Rural Appraisal, IDS Bulletin, Vol. 12, No. 4 (1981).

Lovelace, George W., Sukaesinee Subhadhira and Suchint Simaraks (Eds.), Rapid Rural Appraisal in Northeast Thailand: Case Studies (Khon Kaen, Thailand: KKUFord Rural Systems Research Project, Khon Kaen University, 1988).

McCracken, J. A., "BOBP tries out RRA in Chinnamedu, Tamil Nadu," Bay of Bengal News (June 1990), pp. 25.

McCracken, J. A., Participatory Rapid Rural Appraisal in Gujarat: A Trial Model for the Aga Khan Rural Support Programme (India) (London: IIED, November 1988).

McCracken, J. A., Jules N. Pretty and Gordon R. Conway, An Introduction to Rapid Rural Appraisal for Agricultural Development (London: IIED, 1988).

Maranga, Stella, "Participatory information collection in Kenya and Zimbabwe," in P. W. Daniels et al. (Eds.), Livestock Services for Smallholders (Bogor, Indonesia: Indonesian International Animal Science Research and Development Foundation, 1993).

Mascarenhas, J., "Participatory rural appraisal and participatory learning methods," Forests, Trees and People Newsletter, No. 15/16 (February 1992), pp. 10-17.

Mascarenhas, J., "Transect in PRA," PALM Series IV E (Bangalore: MYRADA, 1990).

Mascarenhas, J., and R. Hildalgo, Experience of $a$
Participatory Rural Appraisal Exercise (Silang, Cavite, Philippines: International Institute for Rural Reconstruction, 1992).

Mascarenhas, J., and P. D. Prem Kumar, "Participatory mapping and modelling: User's notes," RRA Notes, No. 12 (1991), pp. 9-20.

Mascarenhas, J. et al.. (Eds.), "Participatory Rural Appraisal: Proceedings of the February 1991 Bangalore PRA Trainers Workshop," RRA Notes, No. 13 (London: IIED and Bangalore: MYRADA, August 1991).

Maxwell, Simon, "Rapid food security assessment: A pilot exercise in Sudan," RRA Notes, No. 5 (1989).

Mearns, Robin, "Aerial photographs in rapid land resource appraisal, Papua New Guinea," RRA Notes, No. 7 (1989), pp. 12-14A.

Mearns, Robin, D. Shombodon, G. Narangerel, U. Turul, A. Enkhamgalan, B. Myagmarzhav, A. Bayanjargal and B. Bekhsuren, "Direct and indirect uses of wealth ranking in Mongolia," RRA Notes, No. 15 (1992), pp. 29-38.

Moris, Jon R., "Multi-subject farm surveys reconsidered: Some methodological lessons," Paper for the East African Agricultural Economics Society Conference (Dar es Salaam: March 31-April 4, 1970).

Mukherjee, Neela, Participatory Rural Appraisal: Methodology and Applications (New Delhi: Concept Publishing House, 1993).

Naragam, Deepa, Participatory Evaluation: Tools for Managing Change in Water and Sanitation, World Bank Technical Paper Number 207 (Washington, DC: The World Bank, 1993).

Neefjes, Koos, with Hanneke Meijers, Pouk Sok, Pok Panha et al., Participatory Environmental Assessment and Planning for Development, Report on a workshop in Cambodia, November/December 1992 (Oxford: Oxfam, 1993).

NES, et al., Participatory Rural Appraisal Handbook, National Environment Secretariat, Kenya; Clark University; Egerton University; and the Center for International Development and Environment of the World Resources Institute (February 1990).

Norman, D. W., "Rationalising mixed cropping under indigenous conditions: the example of Northern Nigeria," Samaru Research Bulletin, No. 232 (Institute for Agricultural Research, Samaru, Ahmadu Bello University, Zaria, Nigeria) (1975).

OUTREACH, Participatory Approach Development Series 1 (Bangalore: Volunteers for Development, 1993).

PALM Series (Bangalore: MYRADA, 1990).

Participants of Bulwer Workshop, Toward Partnership in Development: A handbook for PRA practitioners, based on a PRA Training Workshop (Bulwer, Natal: April 19-26 1993).

Pelto, Pertti J., and Gretel H. Pelto, Anthropological Research: The Structure of Inquiry, Second edition (Cambridge: Cambridge University Press, 1978).

PID and NES, An Introduction to Participatory Rural Appraisal for Rural Resources Management, Program for International Development, Clark University, Worcester, Mass and National Environment Secretariat, Ministry of Environment and Natural Resources (Nairobi: PID and NES, November 1991).

Potten, D., "Rapid rural appraisal - Emergence of a methodology and its application to irrigation: A bibliographical review," Paper for the Review and Develop- 
ment Seminar on Selected Issues in Irrigation Management (Colombo, Sri Lanka: International Irrigation Management Institute, 1985).

PRA Team, The Kyeamba Valley: Issues of Concern to Landholders and Their Families, Identified in a Participatory Rural Appraisal by Members of the Kyeamba Valley Community, September 1991, compiled by a PRA Team with the following connections: Landcare, Department of Conservation and Land Management, New South Wales Agriculture, School of Agriculture, CSU-R, Centre for Conservation Farming, CSU-R, School of Crop Sciences, The University of Sydney and Wagga Wagga City Council (1991).

Pretty, Jules N., Rapid Catchment Analysis for Extension Agents: Notes on the 1990 Kericho Training Workshop for the Ministry of Agriculture, Kenya, Sustainable Agriculture Programme (London: IIED, November 1990).

Pretty. Jules N., and John Thompson. Soil and Water Conservation Branch, Ministry of Agriculture, Kenya: Trip Report, 17 April-5 May 1993 (London: IIED, May 1993).

Pretty, Jules, S. Subramanian, D. Ananthakrishnan, C. Jayanthi, S. Muralikrishnasamy and K. Renganayaki, "Finding the poorest in a Tamil Nadu Village: A sequence of mapping and wealth ranking," RRA Notes, No. 15 (1992), pp. 39-42.

Rahman, Md Anisur (Ed.), Grassroots Participation and Self-reliance (New Delhi: Oxford and IBH, 1984).

Ramachandran, Vidya, A Workshop on Participatory Learning Methods, 8th to I2th January 1990, MYRADA Talavadi Project, PRA/PALM Series No. 1 (Bangalore: MYRADA, 1990).

Rhoades, Robert, "The coming revolution in methods for rural development research," in N. S. Scrimshaw and G. R. Gleason (Eds.), Rapid Assessment Procedures (Boston: INDFC, 1992), pp. 6178.

Rhoades, Robert, The Art of the Informal Agricultural Survey (Lima: International Potato Center, 1982).

Richards, P., Indigenous Agricultural Revolution (Boulder, CO: Westview Press, 1985).

Rietbergen-McCracken, Jennifer, Diagnostico Rural Rapido: Un Manual (Washington DC: 1991).

Robinson, Eva, "Women's PRA in Hindupur," RRA Notes, No. 17 (1993), pp. 46-48.

RRA Notes (London: Sustainable Agriculture Programme, International Institute for Environment and Development, 1988-).

Sandford, Dick, "A note on the use of aerial photographs for land use planning on a settlement site in Ethiopia," $R R A$ Notes, No. 6 (1989), pp. 18-19.

Schonhuth, Michael, and Uwe Kievelitz, Partizipative Erhebungs- und Planungsmethoden in der Entwicklungszusammenarbeit: Rapid Rural Appraisal, Participatory Appraisal: Eine kommentierte Einfuhrung, Schriftenreihe der GTZ Nr 231 (Eschborn: 1993).

Scoones, Ian, and John Thompson, Challenging the Populist Perspective: Rural People's Knowledge, Agricultural Research and Extension Practice, IDS Discussion Paper 332 (Brighton: Institute of Development Studies, December 1993).

Scrimshaw, Nevin S., and Gary R. Gleason (Eds), RAP Rapid Assessment Procedures: Qualitative Methodologies for Planning and Evaluation of Ilealth Related Programmes (Boston, MA: International Nutrition Foundation for Developing Countries, 1992).
Scrimshaw, S., and E. Hurtado, Rapid Assessment Procedures for Nutrition and Primary Health Care: Anthropological Approaches for Improving Programme Effectiveness (Tokyo: United Nations University; Los Angeles: UNICEF/UN Children's Fund; and UCLA Latin American Center, 1987).

Shah, Parmesh, "Participatory watershed management programmes in India: Reversing our roles and revising our theories," in Rural People's Knowledge, Agricultural Research and Extension Practice, IIED Research Series, Vol. 1, No. 3 (1993), pp. 38-67.

Shah, Parmesh, Girish Bharadwaj and Ranjit Ambastha, "Participatory rural appraisal and planning (PRAP): The experience of the Aga Khan Rural Support Programme," RRA Notes, No. 13 (1991a), pp. 69-83.

Shah, Parmesh, Girish Bharadwaj and Ranjit Ambastha, "Farmers as analysts and facilitators in participatory rural appraisal and planning," RRA Notes, No. 13 (1991b), pp. 84-94.

Shaner, W. W., P. F. Philipp and W. R. Schmehl, Farming Systems Research and Development: Guidelines for Developing Countries (Boulder, CO: Westview Press, 1982).

Sheelu, F., and S. Devaraj, Participatory Rural Appraisal: An Initiation in Tamil Nadu: Experience Sharing (Tamil Nadu, India: The Activists for Social Alternatives (ASA), June 1992).

Slim, Hugo, and P. Thompson, Listening for a Change: Oral Testimony and Development (London: Panos Publications, 1993).

Slim, Hugo, and John Mitchell, "The application of RAP and RRA techniques in emergency relief programmes," in Scrimshaw and Gleason (Eds.), RAP Rapid Assessment Procedures (Boston: INDFC, 1992), pp. 251-256.

Sonaiya, E. B., "An integrative approach to the definition of problems and opportunities for smallholder rural poultry farmers in Nigeria,"P. W. Daniels et al. (Eds.), Livestock Services for Smallholders (Bogor, Indonesia: Indonesia International Animal Science Research and Development Foundation, 1993), pp. 130-132.

SPR in Asia, Participatory Research: An Introduction (New Delhi: Society for Participatory Research in Asia, 1982).

SPWD, Joint Forest Management Field Methods Manual Vol. I Diagnostic Tools for Supporting Joint Forest Management Systems, and Vol. 2 Community Forest Economy and Use Patterns: Participatory Rural Appraisal (PRA) Methods in South Gujarat, India (New Delhi: Society for the Promotion of Wastelands Development, 1992).

Swift, Jeremy, and Abdi Noor Umar, Participatory Pastoral Development in Isiolo District: Socio-economic Research in the Isiolo Livestock Development Project (Isiolo, Kenya: Isiolo Livestock Development Project, EMI ASAL Programme, 1991).

van Steijn, T., "Rapid nural appraisal in the Philippines: Report of a study on the application of RRA by Philippines NGOs, GOs and University Institutes," Draft (Quezon City: Council for People's Development, July 1991).

Theis, J., and H. Grady, Participatory Rapid Appraisal for Community Development: A Training Manual Based on Experiences in the Middle East and North Africa (London: Save the Children and IIED, 1991).

Tolley, Elizabeth, and Margaret E. Bentley, "Participatory 
methods for research on women's reproductive health," RRA Notes, No. 16 (1992), pp. 63-68.

Townsley, Philip, Rapid Appraisal for Coastal Communities (Madras: BOBP-FAO, 1993).

The Women of Sangams, Pastapur and Michel Pinbert, "Farmer Participation in On-farm Varietal Trials: Multilocational testing under resource-poor conditions," RRA Notes, No. 10 (February 1991), pp. 3-8.

Welbourn, A., "A note on the use of disease problem ranking with relation to socio-economic well-being: an example from Sierra Leone," RRA Notes, No. 16 (1992), pp. 86-87.
Welbourn, A., "RRA and the analysis of difference," $R R A$ Notes, No. 14 (December 1991), pp. 14-23.

Whyte, A. V. T., Guidelines for Field Studies in Environmental Perception (Paris: UNESCO, 1977).

Whyte, William Foote (Ed.), Participatory Action Research (Newbury Park, CA: Sage Publications, 1991).

Young, John, "Alternative approaches to the identification of smallholder problems and opportunities," in P. W. Daniels et al. (Eds.), Litestock Services for Smallholders (Bogor, Indonesia: Indonesian International Animal Science Research and Development Foundation, 1993). 